dr hab. Paweł Bryła, prof. UŁ

Uniwersytet Łódzki

Wydział Studiów Międzynarodowych i Politologicznych

Katedra Marketingu Międzynarodowego i Dystrybucji

ROZDZIAt 2

\title{
ZNACZENIE MARKI NA RYNKU EKOLOGICZNYCH PRODUKTÓW ŻYWNOŚCIOWYCH ${ }^{1}$
}

\section{WPROWADZENIE}

Marka odgrywa bardzo istotną rolę na rynku produktów żywnościowych. Przykładowo, w ogólnopolskim badaniu wśród przedsiębiorstw przetwórstwa rolno-spożywczego marka i reputacja firmy została oceniona jako czwarty co do ważności atrybut ich oferty zarówno na rynku krajowym, jak i w eksporcie. Jeszcze większe znaczenie ma na tym rynku gwarancja jakości w postaci certyfikatu bądź oznaczenia² , które również mogą być traktowane jako rodzaje marki. Rynek produktów ekologicznych, który stanowi coraz istotniejszy segment całego rynku żywności, charakteryzuje się nieco innymi postawami i zachowaniami konsumentów niż rynek żywności masowej, zwanej też konwencjonalną. O ile marka i reputacja producenta stanowi szóstą co do ważności determinantę wyboru produktów konwencjonalnych (przy 24,4\% wskazań wśród pięciu najważniejszych kryteriów wyboru), o tyle na rynku żywności ekologicznej marka i reputacja producenta znalazła się dopiero na 13. miejscu wśród kryteriów, którymi kierują się polscy konsumenci (przy zaledwie 14,2\% wskazań wśród pięciu kluczowych determinant zakupu). Także marka i reputacja miejsca sprzedaży ma większe znaczenie na rynku żywności konwencjonalnej w porównaniu z zakupami produktów ekologicznych (odpowiednio 8. i 21. miejsce; 18,0\% i 9,7\%) w Polsce. Natomiast konsumenci żywności ekologicznej przywiązują znacznie większą wagę do gwarancji jakości

${ }^{1}$ Rozdział ten został napisany w ramach projektów badawczych sfinansowanych ze środków Ministerstwa Nauki i Szkolnictwa Wyższego - Iuventus Plus nr IP 2011004371 (projekt realizowany w latach 2012-2014) i Narodowego Centrum Nauki - Opus nr 2015/17/B/HS4/00253 (projekt realizowany w latach 2016-2020).

2 P. Bryła, The impact of EU accession on the marketing strategies of Polish food companies, „British Food Journal", 2012, 114(8), s. 1196-1209. 
w postaci oznaczeń i certyfikatów niż nabywcy produktów konwencjonalnych (odpowiednio 5. i 16. miejsce; 29,4\% i 10,1\%). Warto dodać, że najważniejszym kryterium żywności konwencjonalnej jest cena, a produktów ekologicznych - ich walory zdrowotne ${ }^{3}$.

Niniejsza praca ma na celu ocenę znaczenia marki na rynku ekologicznych produktów żywnościowych, jak również wskazanie czynników mających wpływ na to znaczenie. Osiągnięcie tego celu jest możliwe z uwagi na przeprowadzenie badań ilościowych w dużej próbie konsumentów. Warto podkreślić, że próba cechowała się reprezentatywnością w stosunku do populacji dorosłych mieszkańców Polski (a dokładnie - osób w wieku 15-65 lat), stąd możliwe jest uogólnianie uzyskanych rezultatów.

\section{PRZEGLĄD LITERATURY}

T. Domański i P. Bryła stwierdzili, że podstawowym wyzwaniem dla przedsiębiorstw działających na rynku produktów żywnościowych będzie polityka zarządzania marką oraz związana z nią polityka komunikacji marketingowej z wykorzystaniem najnowszych narzędzi komunikacji za pośrednictwem nowych mediów ${ }^{4}$. W ujęciu B. Pilarczyk i R. Nestorowicz na markę żywności ekologicznej (zwaną w cytowanym opracowaniu także „ekomarką”) składają się następujące elementy: jakość produktów - walory zdrowotne, komunikacja marketingowa, opakowanie ekologiczne, formy sprzedaży, znak żywności ekologicznej, logo i nazwa, tradycja na rynku $u^{5}$. Warto zauważyć, że jest to ujęcie bardzo szerokie, obejmujące zarówno markę producenta, jak i oznaczenia jakości. Według cytowanych autorek ${ }^{6}$, które inspirowały się opracowaniem L. Garbarskiego, I. Rutkowskiego i W. Wrzoska7, marka na rynku żywności ekologicznej pełni funkcję strategicznego instrumentu działania przedsiębiorstwa na rynku oraz wobec nabywców. W pierwszej kategorii wymieniono: odróżnianie żywności ekologicznej od produktów konwencjonalnych, ochronę przed konkurencją, umożliwianie wprowadzania nowych produktów ekologicznych na rynek, ułatwianie reklamy produktu ekologicznego, tworzenie grupy lojalnych nabywców, zwiększanie swobody w ustalaniu ceny. Z punktu widzenia konsumentów marka pełni na tym rynku następujące funkcje:

${ }^{3}$ Idem, Marketing regionalnych i ekologicznych produktów żywnościowych - perspektywa sprzedawcy $i$ konsumenta, Wydawnictwo Uniwersytetu Łódzkiego, Łódź 2015.

${ }^{4}$ T. Domański, P. Bryła, Marketing produktów żywnościowych, PWE, Warszawa 2010, s. 224.

${ }^{5}$ B. Pilarczyk, R. Nestorowicz, Marketing ekologicznych produktów żywnościowych, Wolters Kluwer, Warszawa 2010, s. 143.

${ }^{6}$ Ibid., s. 142.

${ }^{7}$ L. Garbarski, I. Rutkowski, W. Wrzosek, Marketing, PWE, Warszawa 2000, s. 343. 
ułatwianie identyfikacji ekożywności i korzyści z nią związanych, zapewnianie odpowiedniej jakości, skrócenie procesu poszukiwania informacji o produkcie ekologicznym, minimalizacja ryzyka towarzyszącego zakupowi, podwyższanie prestiżu nabywcy w otoczeniu, umożliwianie dbałości o zdrowie.

Oznaczenia ekologiczne mogą być traktowane jako element strategii dyferencjacji marki ${ }^{8}$, a nawet jako rodzaj marki ${ }^{9}$ mogą także sygnalizować jakość. Tego typu sygnały współwystępują z sygnałami marek, tworząc środowisko wspólnego oddziaływania marek, tzw. co-brandingu. Efekt krańcowy oznaczeń ekologicznych jest silniejszy, gdy kapitał marki jest niższy, ale niezależnie od wielkości kapitału marki oznaczenie ekologiczne uwypukla atrybut „bycia przyjaznym dla środowiska”, co ma pozytywny wpływ na postrzeganą jakość produktu ${ }^{10}$. Oznaczenia ekologiczne wpływają na percepcję marek globalnych, lokalnych i handlowych w zakresie motywów wyboru, aczkolwiek prawdopodobieństwo czerpania korzyści z etykiet ekologicznych jest wyższe dla marek dystrybutora niż dla marek producenta na poziomie globalnym czy lokalnym ${ }^{11}$.

Znajomość marki i stosunek do marki wpływają na zachowania zakupowe konsumentów na rynku żywności ekologicznej ${ }^{12}$. Komunikacja marki może odgrywać główną rolę w stymulowaniu świadomości konsumentów, która przekłada się na wzrost zakupów ekologicznych. Wiedza ekologiczna i poziom zaufania konsumentów warunkują skuteczność tej komunikacji13. W kreowaniu wyróżników żywności ekologicznej istotne jest pozycjonowanie marek o dużym zaufaniu oraz budowanie i podtrzymywanie zaufania wobec marek ${ }^{14}$. Produkty ekologiczne są postrzegane bardziej korzystnie od ich konwencjonalnych odpowiedników pod względem wartości odżywczej, bezpieczeństwa, stosunku do marki i zaufania do marki, co świadczy o tzw. efekcie aureoli (halo effect). W badaniu konsumentów

${ }^{8}$ D. Schäfer, D. Heinrich, Green branding: Do local and global brands benefit from organic labeling, [w:] The Sustainable Global Marketplace, red. M. Conway, Springer, Cham 2015, s. 443.

9 J. Stanton, D. Guion, Perceptions of "organic" food: A view through brand theory, "Journal of International Food and Agribusiness Marketing", 2015, 27(2), s. 120-141.

${ }^{10}$ F. Larceneux, F. Benoit-Moreau, V. Renaudin, Why might organic labels fail to influence consumer choices? Marginal labelling and brand equity effects, "Journal of Consumer Policy”, 2012, 35(1), s. 85-104.

${ }^{11}$ H. Bauer, D. Heinrich, D. Schäfer, The effects of organic labels on global, local, and private brands. More hype than substance?, „Journal of Business Research”, 2013, 66(8), s. 1035-1043.

${ }^{12} \mathrm{~J}$. Bartels, K. Hoogendam, The role of social identity and attitudes toward sustainability brands in buying behaviors for organic products, „Journal of Brand Management”, 2011, 18(9), s. 697-708.

${ }^{13}$ T. Anisimova, P. Sultan, The role of brand communications in consumer purchases of organic foods: A research framework, „Journal of Food Products Marketing”, 2014, 20(5), s. 511-532.

${ }^{14}$ M. Grzybowska-Brzezińska, M. Grzywińska-Rąpca, Atrybuty żywności ekologicznej determinujace wybory konsumentów, „Zeszyty Naukowe Szkoły Głównej Gospodarstwa Wiejskiego. Ekonomika i Organizacja Gospodarki Żywnościowej”, 2016, nr 114, s. 57-68. 
amerykańskich efekt ten nie dotyczył oczekiwanego smaku i prawdopodobieństwa zakupu ${ }^{15}$. Kapitał marki pozytywnie oddziałuje zarówno na konsumpcję ekologicznych marek producenta, jak i marek dystrybutora, ale występują pewne różnice między tymi markami w zakresie znaczenia ich tożsamości. Ponadto konsumenci częściej identyfikują się z markami, które mają wyższy kapitał¹6.

Rozwój marek własnych dystrybutora może stanowić okazję do przełamania barier wysokich cen i niskiej dostępności na rynku żywności ekologicznej ${ }^{17}$. Wprowadzenie ekologicznych marek dystrybutora stanowi źródło przewagi konkurencyjnej z uwagi na: nazwę, szerokość asortymentu, typ marek handlowych, wizerunek detalisty, zrównoważony rozwój i atrybuty żywności ekologicznej ${ }^{18}$. Na rynku żywności ekologicznej związek między wartościami i postawami konsumentów zależy od reputacji marki. Gdy jest ona wysoka, motywy wyboru produktów ekologicznych silniej oddziałują na ten związek ${ }^{19}$. W badaniach okulograficznych (eye tracking) okazało się, że konsumenci najwięcej uwagi poświęcają markom żywności ekologicznej, a w mniejszym stopniu koncentrują się na pozostałych elementach graficznych na opakowaniach ${ }^{20}$. Osoby kupujące żywność ekologiczną w Internecie (e-konsumenci) wskazały markę producenta jako dziewiąte co do ważności kryterium wyboru tego rodzaju produktów, markę detalisty jako piętnaste, a gwarancję jakości jako trzecie co do ważności kryterium (przy 31,7\% wskazań wśród pięciu najważniejszych kryteriów) ${ }^{21}$. Marka (rozumiana na wszystkie trzy sposoby) ma większe znaczenie dla osób kupujących żywność ekologiczną w Internecie niż dla konsumentów korzystających z innych kanałów dystrybucji.

15 B. Ellison, B. Duff, Z. Wang, T. White, Putting organic label in context: Examining the interactions between the organic label, product type, and retail outlet, „Food Quality and Preference”, 2016, 49, S. $140-150$.

${ }^{16}$ M. Reinders, J. Bartels, The roles of identity and brand equity in organic consumption behavior: Private label brands versus national brands, „Journal of Brand Management”, 2017, 24(1), s. 68-85.

17 M. Llorens, S. Carcelén, The role of private labels in the organic food market, [w:] Handbook of research on strategic retailing of private label products recovering economy, red. M. Gómez-Suárez, M. Martínez-Ruiz, IGI Global, Hershey 2016, s. 359-387.

${ }^{18}$ H. Górska-Warsewicz, S. Żakowska-Biemans, M. Czeczotko, M. Świątkowska, D. Stangierska, E. Świstak, A. Bobola, J. Szlachciuk, K. Krajewski, Organic private labels as sources of competitive advantage - the case of international retailers operating on the Polish market, "Sustainability”, 2018, 10(7), 2338, s. 1-28.

${ }^{19} \mathrm{~J}$. Ryan, R. Casidy, The role of brand reputation in organic food consumption: A behavioral reasoning perspective, „Journal of Retailing and Consumer Services”, 2018, 41, s. 239-247.

20 D. Drexler, J. Fiala, A. Havlíčková, A. Potůčková, M. Souček, The effect of organic food labels on consumer attention, „Journal of Food Products Marketing”, 2018, 24(4), s. 441-455.

${ }^{21}$ P. Bryła, Organic food online shopping in Poland, „British Food Journal”, 2018, 120(5), s. 1015-1027. 


\section{MATERIAŁ I METODYKA}

Przeprowadzono badanie ankietowe wśród polskich konsumentów. Próba składała się z 1000 osób w wieku 15-65 lat. Była reprezentatywna w stosunku do populacji generalnej pod względem: wieku, płci, wykształcenia i miejsca zamieszkania (wielkości miejscowości). Na zlecenie Uniwersytetu Łódzkiego ankietę przeprowadziła wyspecjalizowana agencja badań marketingowych (ARC Rynek i Opinia) w swoim panelu internetowym (epanel.pl) przy użyciu metodologii CAWI (Computer Assisted Web Interview) w 2014 r. Bardziej szczegółowa charakterystyka próby badanej jest dostępna $\mathrm{w}$ książce ${ }^{22} \mathrm{i}$ poprzednich artykułach powstałych w ramach tego projektu ${ }^{23}$. W niniejszej publikacji skoncentrowano się na respondentach, którzy zadeklarowali kierowanie się marką podczas zakupu żywności ekologicznej, porównując ich cechy charakterystyczne, postawy i opinie z resztą próby. Markę ujęto na trzech poziomach agregacji:

1) wyłącznie marka producenta;

2) marka producenta i sprzedawcy;

3) marka producenta, sprzedawcy i oznaczenia jakości.

Do analizy wyników zastosowano tabele krzyżowe, testy $t$, współczynniki $\chi^{2}$ i modele regresji logistycznej. Obliczeń dokonano w programach Microsoft Excel 2013 i Statistica 12.0.

\section{WYNIKI}

Respondenci zostali poproszeni o wskazanie pięciu najważniejszych kryteriów, którymi kierują się podczas zakupu ekologicznych produktów żywnościowych (tab. 2.1). Katalog odpowiedzi obejmował 26 opcji, w tym przewidziano możliwość podania niewymienionego powodu (pytanie półotwarte). W całej próbie (CP) najważniejsze okazały się walory zdrowotne $(50,6 \%)$ i ekologiczny charakter produktu (46,9\%). Tylko 14,2\% badanych wymieniło markę i reputację producenta jako jedno z pięciu najważniejszych kryteriów wyboru żywności ekologicznej. Marka i reputacja miejsca sprzedaży była jeszcze rzadziej wskazywana wśród pięciu najważniejszych determinant wyboru ekologicznych produktów żywnościowych (9,7\%). Natomiast prawie $1 / 3$ badanych uznała, że do tych najważniejszych kryteriów wyboru należy gwarancja jakości w postaci certyfikatu bądź oznaczenia (29,4\%). W tym rozdziale skupiono się na analizie grup respondentów, dla których

\footnotetext{
${ }^{22}$ Idem, Marketing regionalnych i ekologicznych..., op.cit.

${ }^{23}$ Idem, The role of appeals to tradition in origin food marketing: a survey among Polish consumers, „Appetite”, 2015, 91, s. 302-310; Idem, Organic food consumption in Poland: motives and barriers, „Appetite”, 2016, 105, s. 737-746.
} 
Tabela 2.1. Kryteria wyboru ekologicznych produktów żywnościowych

\begin{tabular}{|c|c|c|c|c|}
\hline Kryteria & EM1 & EM2 & EM3 & $\mathrm{CP}$ \\
\hline marka i reputacja producenta & 100,0 & 64,8 & 31,4 & 14,2 \\
\hline gwarancja jakości (certyfikat, oznaczenie) & 26,1 & 27,9 & 65,0 & 29,4 \\
\hline tradycyjna receptura & 19,7 & 19,2 & 20,1 & 21,3 \\
\hline ekologiczny charakter produktu & 35,2 & 37,4 & 44,5 & 46,9 \\
\hline identyfikacja produktów z danym regionem & 9,9 & 9,1 & 6,9 & 6,9 \\
\hline troska o dobrostan zwierząt gospodarskich & 5,6 & 7,3 & 7,7 & 10,0 \\
\hline troska o lokalnych producentów & 7,0 & 8,2 & 7,3 & 7,2 \\
\hline nostalgia & 2,8 & 2,7 & 2,0 & 2,8 \\
\hline moda na konsumpcję takiej żywności & 25,4 & 21,5 & 23,5 & 24,7 \\
\hline ciekawość & 12,7 & 13,7 & 13,1 & 16,6 \\
\hline lojalność & 5,6 & 4,6 & 3,8 & 5,4 \\
\hline śledzenie źródeł pochodzenia surowców & 11,3 & 11,9 & 12,2 & 12,7 \\
\hline cena & 20,4 & 17,4 & 16,2 & 17,8 \\
\hline smak & 24,6 & 26,0 & 26,3 & 30,0 \\
\hline zapach & 9,2 & 10,5 & 9,3 & 14,6 \\
\hline zdrowotność & 43,0 & 39,7 & 48,0 & 50,6 \\
\hline bezpieczeństwo spożycia & 26,1 & 25,1 & 27,2 & 30,4 \\
\hline termin przydatności do spożycia & 10,6 & 10,5 & 10,8 & 10,7 \\
\hline niepowtarzalność produktu & 13,4 & 14,2 & 14,2 & 13,2 \\
\hline marka i reputacja miejsca sprzedaży & 14,1 & 44,3 & 21,5 & 9,7 \\
\hline dostępność w pobliżu miejsca zamieszkania & 12,0 & 13,2 & 12,6 & 12,5 \\
\hline przyjemność konsumpcji & 11,3 & 11,9 & 12,2 & 14,3 \\
\hline bogactwo składników mineralnych, witamin & 24,6 & 22,8 & 25,2 & 26,1 \\
\hline reklama & 12,0 & 11,4 & 9,1 & 12,0 \\
\hline opinie członków rodziny/znajomych & 6,3 & 9,1 & 9,7 & 11,1 \\
\hline inny powód & 0 & 0 & 0 & 0,7 \\
\hline
\end{tabular}

Uwaga: EM1 - respondenci, dla których marka i reputacja producenta znajdują się wśród pięciu najważniejszych kryteriów wyboru ekologicznych produktów żywnościowych (142 osoby); EM2 - respondenci, dla których marka i reputacja producenta lub miejsca sprzedaży znajdują się wśród pięciu najważniejszych kryteriów wyboru ekologicznych produktów żywnościowych (219 osób); EM3 - respondenci, dla których marka i reputacja producenta lub miejsca sprzedaży, lub gwarancja jakości (certyfikat, oznaczenie) znajdują się wśród pięciu najważniejszych kryteriów wyboru ekologicznych produktów żywnościowych (452 osoby); CP - cała próba (1000 osób).

Źródło: badanie własne. 
marka stanowi jedno z podstawowych kryteriów wyboru żywności ekologicznej. W opinii autora, marka na rynku produktów ekologicznych może być definiowana przynajmniej na trzech poziomach:

1) w odniesieniu do producenta;

2) w odniesieniu do miejsca sprzedaży;

3) w odniesieniu do oznaczenia jakości.

Oznaczenia jakości, w szczególności europejskie logo rolnictwa ekologicznego, mają kluczowe znaczenie dla identyfikacji żywności ekologicznej, dlatego niewątpliwie noszą znamiona marki. Dodatkowym, czwartym poziomem mogłaby być marka obszaru pochodzenia, jeśli jest on akcentowany w komunikacji marketingowej producenta żywności ekologicznej.

W tym rozdziale do dalszych analiz wyodrębniono trzy grupy respondentów na podstawie ich preferencji dotyczących marki. Pierwsza grupa (EM1) składa się z osób, dla których marka i reputacja producenta znajdują się wśród pięciu najważniejszych kryteriów wyboru ekologicznych produktów żywnościowych. Jej liczebność jest stosunkowo niewielka - 142 spośród 1000 badanych. Druga grupa (EM2) obejmuje wszystkich respondentów z pierwszej grupy i dodatkowo osoby, dla których marka i reputacja miejsca sprzedaży znajdują się wśród pięciu najważniejszych kryteriów wyboru ekologicznych produktów żywnościowych. Łącznie było to 219 respondentów. Trzecia grupa (EM3) - najszersza - składa się z respondentów, dla których marka i reputacja producenta lub miejsca sprzedaży albo gwarancja jakości (certyfikat, oznaczenie) znajdują się wśród pięciu najważniejszych kryteriów wyboru ekologicznych produktów żywnościowych. Przy takim określeniu marki prawie połowa badanych (452 osoby) wskazała ją jako jedno z pięciu najważniejszych kryteriów wyboru żywności ekologicznej.

Marka i reputacja producenta stanowi kluczowe kryterium wyboru dla wszystkich respondentów z grupy EM1 (z definicji), jak również dla prawie 2/3 badanych z grupy EM2 (64,8\%) i prawie 1/3 z grupy EM3 (31,4\%) wobec zaledwie 1/7 (14,2\%) w całej próbie. Marka i reputacja miejsca sprzedaży jest bardziej istotna w grupach EM1, EM2 i EM3 w porównaniu z całą próbą. Ta cecha ma szczególnie duże znaczenie w grupie EM2 (44,3\%). Natomiast gwarancja jakości w postaci certyfikatu bądź oznaczenia (najczęściej obie te formy występują łącznie) była bardzo ważnym kryterium dla prawie $2 / 3$ badanych z grupy EM3 (65,0\%), a w grupach EM1 i EM2 czynnik ten był stosunkowo mniej istotny niż w całej próbie (26,1\% i $27,9 \%$ wobec $29,4 \%$ ). Można przypuszczać, że wynikało to z pewnej substytucyjności w procesie podejmowania decyzji przez konsumentów między markami producenta a markami kolektywnymi w postaci oznaczeń jakości. W związku z większym znaczeniem marki w grupach EM1, EM2 i EM3 w porównaniu z całą próbą inne kryteria wyboru są tam z reguły nieco mniej istotne niż w całej próbie. 
Różnice te są szczególnie widoczne dla EM1. Tylko 35,2\% respondentów z tej grupy wskazało na kierowanie się ekologicznym charakterem produktu wobec 46,9\% w całej próbie. Także zdrowotność była relatywnie mniej istotna w EM1 niż w CP (43,0\% w porównaniu z 50,6\%). Wyraźnie mniej osób w EM1 kierowało się opiniami członków rodziny lub znajomych (6,3\% wobec $11,1 \%$ w całej próbie) i smakiem produktów (24,6\% v. 30,0\%). Co ciekawe, identyfikacja produktów z regionem konsumenta miała większe znaczenie w EM1 i EM2 niż w całej próbie. Może to być związane z preferencjami wobec marek z własnego regionu i kraju, a zatem ze zjawiskiem etnocentryzmu konsumenckiego.

Tabela 2.2. Struktura badanych według płci (\%)

\begin{tabular}{|l|c|c|c|c|}
\hline \multicolumn{1}{|c|}{ Płeć } & EM1 & EM2 & EM3 & CP \\
\hline kobieta & 47,89 & 47,95 & 50,88 & 50,10 \\
\hline mężczyzna & 52,11 & 52,05 & 49,12 & 49,90 \\
\hline razem & 100,00 & 100,00 & 100,00 & 100,00 \\
\hline
\end{tabular}

Uwaga: EM1: $\chi^{2}$ Yatesa $=0,229, p=0,632 ; \mathrm{EM} 2: \chi^{2}$ Yatesa $=0,416, p=0,519, \mathrm{EM} 3: \chi^{2}$ Yatesa $=$ $0,150, p=0,699$.

Źródto: badanie własne.

Aby lepiej poznać zjawisko kierowania się marką w procesie zakupu żywności ekologicznej, scharakteryzowano grupy EM1, EM2 i EM3 w porównaniu z całą próbą pod względem wybranych cech społeczno-demograficznych. Cała próba dobrze odzwierciedlała populację generalną dorosłych mieszkańców Polski, a dokładniej - osób w wieku 15-65 lat. Pod względem płci nie stwierdzono różnic istotnych statystycznie dla żadnego agregatu marki (tab. 2.2). Inaczej sytuacja wygląda w zakresie wieku. Otóż średni wiek osób w grupie EM1 wyniósł 41,96 roku, podczas gdy wśród pozostałych badanych (P1 = CP - EM1 = 1000 - $142=858$ osób) było to 38,76 roku. Różnica ta była istotna statystycznie $(t=2,57, p=0,010)$, czyli osoby kierujące się marką producenta były przeciętnie starsze. Średni wiek dla EM2 wyniósł 40,66 roku wobec 38,81 roku dla pozostałych (P2 $=\mathrm{CP}-\mathrm{EM} 2=1000-219=$ 781 osób), ale ta różnica nie osiągnęła istotności statystycznej ( $t=1,75, p=0,080)$. W najszerszym agregacie EM3 przeciętny wiek wyniósł 40,52 roku wobec 38,14 roku dla pozostałych (P3 = CP - EM3 = 1000 - $452=548$ osób). Osoby należące do grupy

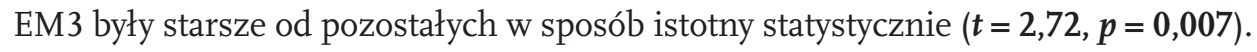

Nie stwierdzono istotnych statystycznie różnic w poziomie wykształcenia osób kierujących się marką w procesie zakupu żywności ekologicznej i pozostałych respondentów (tab. 2.3). Wynik ten nie zależy od sposobu zdefiniowania marki różnice dla wszystkich trzech analizowanych agregatów są nieistotne. 
Tabela 2.3. Struktura badanych według poziomu wykształcenia

\begin{tabular}{|l|c|c|c|c|}
\hline \multicolumn{1}{|c|}{ Wykształcenie } & EM1 & EM2 & EM3 & CP \\
\hline podstawowe & 43,66 & 43,84 & 42,70 & 42,00 \\
\hline średnie & 34,61 & 34,25 & 37,61 & 36,80 \\
\hline wyższe & 21,83 & 21,92 & 19,69 & 21,20 \\
\hline razem & 100,00 & 100,00 & 100,00 & 100,00 \\
\hline
\end{tabular}

Uwaga: EM1: $\chi^{2}=0,376, p=0,828 ; \mathrm{EM} 2: \chi^{2}=0,790, p=0,674$, EM3: $\chi^{2}=1,130, p=0,568$.

Źródło: badanie własne.

Nie odnotowano także różnic istotnych statystycznie w zakresie rodzaju aktywności zawodowej respondentów wskazujących na kluczowe znaczenie marki podczas zakupu ekologicznych produktów żywnościowych i pozostałych badanych (tab. 2.4). Warto jednak zauważyć, że marka i reputacja producenta były rzadziej wskazywane jako istotne kryteria wyboru żywności ekologicznej przez studentów i osoby nieaktywne zawodowo.

Tabela 2.4. Struktura badanych według aktywności zawodowej

\begin{tabular}{|l|r|r|r|r|}
\hline \multicolumn{1}{|c|}{ Aktywność zawodowa } & EM1 & EM2 & EM3 & Razem \\
\hline pracownik umysłowy & 31,69 & 31,05 & 28,32 & 28,10 \\
\hline pracownik fizyczny & 34,51 & 31,51 & 31,64 & 31,80 \\
\hline bezrobotny & 7,75 & 5,94 & 7,52 & 7,20 \\
\hline student & 10,56 & 11,87 & 12,17 & 13,70 \\
\hline nie pracuje i zajmuje się rodziną & 4,23 & 6,39 & 6,64 & 6,90 \\
\hline emeryt/rencista & 9,15 & 10,96 & 11,50 & 9,80 \\
\hline inne & 2,11 & 2,28 & 2,21 & 2,50 \\
\hline razem & 100,0 & 100,00 & 100,00 & 100,00 \\
\hline
\end{tabular}

Uwaga: EM1: $\chi^{2}=4,283, p=0,638$; EM2: $\chi^{2}=2,724, p=0,843$, EM3: $\chi^{2}=4,353, p=0,629$.

Źródto: badanie własne.

Struktura badanych pod względem regionu, w którym mieszkają, nie wykazuje różnic istotnych statystycznie między respondentami podkreślającymi duże znaczenie marki na rynku ekologicznych produktów żywnościowych i kierującymi się odmiennymi kryteriami wyboru tego typu żywności (tab. 2.5). Mimo to różnice 
dotyczące poszczególnych województw są czasem znaczne, np. w województwie dolnośląskim mieszka prawie dwa razy więcej osób kierujących się marką, niż wynosi odsetek respondentów z całej próby zamieszkujących w tym województwie. Natomiast w województwie opolskim to kryterium wyboru ma wyraźnie mniejsze znaczenie, niż wskazywałby udział badanych w całej próbie.

Tabela 2.5. Struktura badanych według miejsca zamieszkania - województwo

\begin{tabular}{|l|r|r|r|r|}
\hline \multicolumn{1}{|c|}{ Województwo } & EM1 & EM2 & EM3 & CP \\
\hline dolnośląskie & 10,56 & 8,22 & 6,64 & 5,90 \\
\hline kujawsko-pomorskie & 7,75 & 5,94 & 5,97 & 6,20 \\
\hline lubelskie & 4,23 & 3,65 & 4,65 & 5,40 \\
\hline lubuskie & 2,82 & 2,74 & 3,76 & 2,80 \\
\hline łódzkie & 7,04 & 5,48 & 7,52 & 6,80 \\
\hline małopolskie & 9,15 & 10,05 & 9,29 & 10,00 \\
\hline mazowieckie & 14,08 & 15,98 & 14,60 & 14,90 \\
\hline opolskie & 0,70 & 1,37 & 1,99 & 2,50 \\
\hline podkarpackie & 6,34 & 5,02 & 4,87 & 5,50 \\
\hline podlaskie & 4,23 & 4,11 & 3,10 & 2,90 \\
\hline pomorskie & 5,63 & 5,48 & 7,96 & 7,00 \\
\hline śląskie & 14,79 & 15,07 & 13,05 & 13,30 \\
\hline świętokrzyskie & 0,70 & 1,83 & 2,21 & 2,20 \\
\hline warmińsko-mazurskie & 4,23 & 4,11 & 5,09 & 4,60 \\
\hline wielkopolskie & 4,93 & 6,85 & 6,19 & 7,10 \\
\hline zachodniopomorskie & 2,82 & 4,11 & 3,10 & 2,90 \\
\hline razem & 100,00 & 100,00 & 100,00 & 100,00 \\
\hline
\end{tabular}

Uwaga: EM1: $\chi^{2}=14,269, p=0,505$; EM2: $\chi^{2}=11,429, p=0,722$, EM3: $\chi^{2}=9,703, p=0,838$.

Źródło: badanie własne.

Wielkość miejscowości, w której mieszkają respondenci, miała istotne statystycznie znaczenie dla agregatu marki EM1 $\left(\chi^{2}=15,968, p=0,014\right)$, tzn. osoby kierujące się marką częściej mieszkały w dużych miastach (tab. 2.6). Na poziomie EM2 ta zależność była istotna statystycznie w sposób marginalny $(p<0,1)$, a przy uwzględnieniu najszerszego ujęcia marki (EM3) - traciła swoją istotność statystyczną. 
Tabela 2.6. Struktura badanych według miejsca zamieszkania - wielkość miejscowości

\begin{tabular}{|c|c|c|c|r|}
\hline \multicolumn{1}{|c|}{ Miejsce zamieszkania } & EM1 & EM2 & EM3 & Razem \\
\hline wieś & 33,80 & 36,07 & 38,72 & 39,00 \\
\hline miasto do 20 tys. & 14,79 & 15,53 & 12,83 & 12,30 \\
\hline $20-50$ tys. & 2,82 & 5,48 & 9,07 & 10,40 \\
\hline 50-100 tys. & 10,56 & 9,59 & 8,85 & 8,40 \\
\hline $100-200$ tys. & 11,27 & 10,05 & 9,73 & 8,40 \\
\hline $200-500$ tys. & 12,68 & 10,05 & 7,96 & 9,60 \\
\hline$>500$ tys. & 14,08 & 13,24 & 12,83 & 11,90 \\
\hline razem & 100,00 & 100,00 & 100,00 & 100,00 \\
\hline
\end{tabular}

Uwaga: EM1: $\chi^{2}=15,968, p=0,014 ; \operatorname{EM} 2: \chi^{2}=11,374, p=0,077$ EM3: $\chi^{2}=6,455, p=0,374$.

Źródto: badanie własne.

Należy podkreślić, że wielkość gospodarstwa domowego respondenta miała istotne znaczenie dla kryterium kierowania się marką podczas zakupu żywności ekologicznej. Warto zauważyć, że różnice istotne statystycznie występowały w przypadku tej cechy na wszystkich poziomach definiowania marki. Marką kierowały się częściej osoby mające mniej liczne rodziny. Dla marki producenta różnicę w wielkości gospodarstw domowych osób podających ją jako jedno z pięciu najważniejszych kryteriów wyboru żywności ekologicznej i pozostałych odzwierciedlają następujące wskaźniki: EM1 $=3,282, \mathrm{P} 1=3,563, t=-2,20, p=\mathbf{0 , 0 2 8}$. W przypadku marki producenta i miejsca sprzedaży zaobserwowano następującą różnicę: $\mathrm{EM} 2=3,352, \mathrm{P} 2=3,571, t=-\mathbf{2}, \mathbf{0 3}, \boldsymbol{p}=\mathbf{0 , 0 4 2}$, a w odniesieniu do najszerszego agregatu marki (obejmującego markę producenta, miejsca sprzedaży i oznaczenia jakości) wielkość gospodarstwa domowego wyniosła odpowiednio $\mathrm{EM} 3=3,42, \mathrm{P} 3=\mathbf{3}, 61, \boldsymbol{t}=\mathbf{- 2}, \mathbf{0 4}, \boldsymbol{p}=\mathbf{0 , 0 4 1}$. Można by przypuszczać, że powyższe wyniki mogą mieć związek z niższą zamożnością większych gospodarstw domowych. Rzeczywiście dane na temat przeciętnych miesięcznych dochodów netto w przeliczeniu na członka gospodarstwa domowego wskazują na zakładane różnice, choć nie miały one istotności statystycznej (EM1 $=1604,02, P 1=1424,53$, $t=1,95, p=0,051$; $\mathrm{EM} 2=1503,37, \mathrm{P} 2=1435,15, t=0,88, p=0,380$; EM3 $=1492,62$, $\mathrm{P} 3=1414,42, t=1,21, p=0,227)$. Zatem czynnik dochodowy nie jest wystarczający do wyjaśnienia powyższych różnic dotyczących wielkości gospodarstw domowych. Dodatkowy wpływ może mieć wiek dzieci w danej rodzinie, który może oddzia- 
ływać na relatywne znaczenie poszczególnych kryteriów wyboru żywności ekologicznej, w tym marki. Jednakże ta cecha nie była przedmiotem naszego badania.

Poproszono respondentów o określenie znaczenia, które mają dla nich wybrane cechy produktów żywnościowych. Katalog odpowiedzi obejmował pięć możliwości (od „bardzo duże” do „bez znaczenia”). Zostały one zakodowane w skali od 1 do 5 , w której 5 oznaczało bardzo duże znaczenie. Badaniem objęto następujące cechy produktów żywnościowych: obszar pochodzenia, cenę, oznaczenia jakości, markę, zaufanie do miejsca sprzedaży i wygląd produktu. Należy podkreślić, że to pytanie dotyczyło całego rynku produktów żywnościowych, nie tylko ekologicznych. W tabeli 2.7 przedstawiono różnice w ocenach poszczególnych atrybutów w zależności od znaczenia przypisywanego marce w procesie zakupu żywności ekologicznej. Dla marki producenta (EM1) nie odnotowano różnic istotnych statystycznie. Mimo że marka na rynku żywności była bardziej istotna dla osób, dla których marka producenta jest kluczowa na rynku żywności ekologicznej, to różnica ta nie była istotna statystycznie $(p>0,05)$. Co zaskakujące, cena była ważniejsza dla osób wskazujących duże znaczenie marki na rynku żywności ekologicznej niż dla pozostałych respondentów, ale ta różnica także nie osiągnęła istotności statystycznej. Gdy przyjmie się szersze ujęcie marki na rynku żywności ekologicznej (EM2), uzyska się istotną różnicę w zakresie znaczenia marki na całym rynku żywności $(\boldsymbol{p}=\mathbf{0 , 0 4 8 )}$. Dla trzeciego agregatu marki żywności ekologicznej (EM3) istotność statystyczną uzyskano dla dwóch atrybutów produktów żywnościowych: oznaczeń jakości $(\boldsymbol{p}<\mathbf{0 , 0 0 1 )}$ i marki $(\boldsymbol{p}=\mathbf{0 , 0 0 3 )}$. Wyniki te wskazują na pewną spójność w opiniach respondentów. Kierowanie się marką na rynku żywności ekologicznej jest związane ze znaczeniem tego atrybutu dla całego rynku żywności. Zależność ta jest widoczna w pełni dopiero wówczas, gdy marka zostanie zdefiniowana bardziej kompleksowo niż tylko na poziomie producenta.

Analizie poddano opinie respondentów na temat produktów ekologicznych w porównaniu ze „zwykłą” (konwencjonalną, masową) żywnością (tab. 2.8). Odpowiedzi zostały zakodowane w skali pięciostopniowej (od „zdecydowanie nie” do „zdecydowanie tak”). Gdy marka była definiowana na poziomie producenta lub producenta i sprzedawcy, nie odnotowano istotnych statystycznie różnic między opiniami osób kierujących się marką (EM1 i EM2) i pozostałych (P1 i P2). Natomiast uwzględnienie oznaczeń jakości w pojęciu marki powoduje wystąpienie istotnych różnic w opiniach na temat żywności ekologicznej. Osoby kierujące się marką definiowaną szeroko (EM2) zdecydowanie częściej wyrażają opinie, że produkty ekologiczne mają wyższą jakość w porównaniu z produktami konwencjonalnymi $(p=0,012)$, mają wyższą cenę $(p=0,024)$, są postrzegane jako bardziej autentyczne $(p=0,012)$, podlegają ściślejszej kontroli $(p<0,001)$, są zdrowsze 
$(p=0,036)$ i mają lepszy wygląd $(p=0,017)$. To ostatnie stwierdzenie może nieco dziwić, gdyż to właśnie produkty ekologiczne często nie podlegają standaryzacji i mają mniej atrakcyjne, nietypowe kształty i kolory. Być może taka ocena respondentów wynikała raczej z utożsamiania lepszego wyglądu z naturalnością produktów niż z atrakcyjnością wizualną.

Tabela 2.7. Ocena znaczenia wybranych cech produktów żywnościowych

\begin{tabular}{|c|c|c|c|c|}
\hline \multirow{2}{*}{ Cecha } & \multicolumn{4}{|c|}{ Marka w wąskim ujęciu } \\
\hline & EM1 & P1 & $t$ & $p$ \\
\hline obszar pochodzenia & 3,58 & 3,53 & 0,51 & 0,607 \\
\hline cena & 4,46 & 4,35 & 1,74 & 0,081 \\
\hline oznaczenia jakości & 3,93 & 3,88 & 0,66 & 0,506 \\
\hline marka & 3,63 & 3,48 & 1,83 & 0,068 \\
\hline zaufanie do miejsca sprzedaży & 3,92 & 3,93 & $-0,16$ & 0,872 \\
\hline \multirow[t]{3}{*}{ wygląd produktu } & 4,08 & 4,02 & 0,77 & 0,439 \\
\hline & \multicolumn{4}{|c|}{ Marka w szerszym ujęciu } \\
\hline & EM2 & P2 & $t$ & $p$ \\
\hline obszar pochodzenia & 3,61 & 3,52 & 1,03 & 0,304 \\
\hline cena & 4,44 & 4,35 & 1,76 & 0,078 \\
\hline oznaczenia jakości & 3,97 & 3,86 & 1,67 & 0,096 \\
\hline marka & 3,61 & 3,47 & 1,98 & 0,048 \\
\hline zaufanie do miejsca sprzedaży & 3,93 & 3,92 & 0,08 & 0,935 \\
\hline \multirow[t]{3}{*}{ wygląd produktu } & 4,12 & 4,01 & 1,74 & 0,082 \\
\hline & \multicolumn{4}{|c|}{ Marka w najszerszym ujęciu } \\
\hline & EM3 & P3 & $t$ & $p$ \\
\hline obszar pochodzenia & 3,56 & 3,52 & 0,60 & 0,550 \\
\hline cena & 4,39 & 4,34 & 1,07 & 0,286 \\
\hline oznaczenia jakości & 3,99 & 3,79 & 3,54 & $<0,001$ \\
\hline marka & 3,60 & 3,42 & 2,96 & 0,003 \\
\hline zaufanie do miejsca sprzedaży & 3,96 & 3,90 & 0,90 & 0,370 \\
\hline wygląd produktu & 4,08 & 3,99 & 1,43 & 0,153 \\
\hline
\end{tabular}

Źródło: badanie własne. 
Tabela 2.8. Opinie na temat produktów ekologicznych w porównaniu ze zwykłymi

\begin{tabular}{|c|c|c|c|c|}
\hline Opinia & EM1 & P1 & $t$ & $p$ \\
\hline Mają wyższą jakość & 3,94 & 3,95 & $-0,03$ & 0,974 \\
\hline Mają wyższą cenę & 4,28 & 4,26 & 0,28 & 0,777 \\
\hline Są bardziej autentyczne & 3,83 & 3,85 & $-0,28$ & 0,781 \\
\hline Są smaczniejsze & 3,81 & 3,80 & 0,08 & 0,937 \\
\hline Są produkowane w bardziej tradycyjny sposób & 3,89 & 3,87 & 0,19 & 0,850 \\
\hline Są bardziej przyjazne dla środowiska & 4,06 & 4,15 & $-1,12$ & 0,263 \\
\hline Podlegają ściślejszej kontroli & 3,97 & 3,92 & 0,57 & 0,571 \\
\hline Są zdrowsze & 4,11 & 4,18 & $-0,86$ & 0,390 \\
\hline Wzbudzają większe zaufanie & 3,92 & 3,98 & $-0,65$ & 0,515 \\
\hline Są lepiej reklamowane & 3,30 & 3,24 & 0,55 & 0,583 \\
\hline Mają lepszy wygląd & 3,54 & 3,53 & 0,06 & 0,956 \\
\hline Akceptuję ich wyższą cenę & 3,42 & 3,42 & 0,04 & 0,968 \\
\hline \multirow[t]{2}{*}{ Polecam ich zakup rodzinie/znajomym } & 3,67 & 3,69 & $-0,26$ & 0,794 \\
\hline & EM2 & P2 & $t$ & $p$ \\
\hline Mają wyższą jakość & 3,96 & 3,94 & 0,32 & 0,751 \\
\hline Mają wyższą cenę & 4,26 & 4,27 & $-0,14$ & 0,886 \\
\hline Są bardziej autentyczne & 3,84 & 3,85 & $-0,20$ & 0,845 \\
\hline Są smaczniejsze & 3,85 & 3,79 & 0,80 & 0,425 \\
\hline Są produkowane w bardziej tradycyiny sposób & 3,86 & 3,88 & $-0,25$ & 0,802 \\
\hline Są bardziej przyjazne dla środowiska & 4,07 & 4,15 & $-1,14$ & 0,253 \\
\hline Podlegają ściślejszej kontroli & 3,94 & 3,93 & 0,09 & 0,927 \\
\hline Są zdrowsze & 4,12 & 4,18 & $-0,92$ & 0,360 \\
\hline Wzbudzają większe zaufanie & 3,94 & 3,98 & $-0,60$ & 0,552 \\
\hline Są lepiej reklamowane & 3,37 & 3,22 & 1,83 & 0,068 \\
\hline Mają lepszy wygląd & 3,62 & 3,51 & 1,46 & 0,146 \\
\hline Akceptuję ich wyższą cenę & 3,35 & 3,44 & $-0,99$ & 0,322 \\
\hline Polecam ich zakup rodzinie/znajomym & 3,67 & 3,69 & $-0,30$ & 0,763 \\
\hline
\end{tabular}


Tabela 2.8. cd.

\begin{tabular}{|l|c|c|c|c|}
\hline & EM3 & P3 & $t$ & $p$ \\
\hline Mają wyższą jakość & 4,03 & 3,88 & 2,52 & $\mathbf{0 , 0 1 2}$ \\
\hline Mają wyższą cenę & 4,33 & 4,21 & $\mathbf{2 , 2 6}$ & $\mathbf{0 , 0 2 4}$ \\
\hline Są bardziej autentyczne & 3,93 & 3,78 & 2,51 & $\mathbf{0 , 0 1 2}$ \\
\hline Są smaczniejsze & 3,85 & 3,76 & 1,44 & 0,149 \\
\hline Są produkowane w bardziej tradycyjny sposób & 3,93 & 3,82 & 1,92 & 0,055 \\
\hline Są bardziej przyjazne dla środowiska & 4,19 & 4,09 & 1,88 & 0,060 \\
\hline Podlegają ściślejszej kontroli & 4,05 & 3,83 & 3,74 & $<\mathbf{0 , 0 0 1}$ \\
\hline Są zdrowsze & 4,23 & 4,12 & $\mathbf{2 , 1 0}$ & $\mathbf{0 , 0 3 6}$ \\
\hline Wzbudzają większe zaufanie & 4,03 & 3,92 & 1,94 & 0,052 \\
\hline Są lepiej reklamowane & 3,30 & 3,21 & 1,31 & 0,191 \\
\hline Mają lepszy wygląd & 3,61 & 3,46 & 2,40 & $\mathbf{0 , 0 1 7}$ \\
\hline Akceptuję ich wyższą cenę & 3,49 & 3,36 & 1,71 & 0,088 \\
\hline Polecam ich zakup rodzinie/znajomym & 3,75 & 3,64 & 1,71 & 0,087 \\
\hline
\end{tabular}

Źródło: badanie własne.

Na podstawie odpowiedzi w tej części ankiety opracowano wskaźnik pod nazwą „stosunek do konsumpcji produktów ekologicznych”. Wskaźnik ten został zoperacjonalizowany jako średnia arytmetyczna ocen w skali 1-5, gdzie 1 oznacza „zdecydowanie nie”, a 5 - „zdecydowanie tak”, dla 12 pozytywnych opinii (mają wyższą jakość, są bardziej autentyczne, są smaczniejsze, są produkowane w bardziej tradycyjny sposób, są bardziej przyjazne dla środowiska, podlegają ściślejszej kontroli, są zdrowsze, wzbudzają większe zaufanie, są lepiej reklamowane, mają lepszy wygląd, akceptuję ich wyższą cenę, polecam ich zakup rodzinie/ znajomym), zatem im wyższa wartość tego wskaźnika, tym bardziej korzystny stosunek do produktów ekologicznych. W zależności od definicji marki wskaźnik ten przyjmuje następujące wartości dla osób kierujących się marką w porównaniu z pozostałymi respondentami: $\mathrm{EM} 1=3,89, \mathrm{P} 1=3,80, t=-0,17, p=0,866$; $\mathrm{EM} 2=$ $3,80, \mathrm{P} 2=3,80, t=0,03, p=0,974 ; \mathrm{EM} 3=3,87, \mathrm{P} 3=3,74, t=2,86, p=0,004$. Należy podkreślić, że tylko przy najszerszym ujęciu marki (uwzględniającym oznaczenia jakości) odnotowano istotne statystycznie różnice w zakresie stosunku do żywności ekologicznej między osobami kierującymi się marką a pozostałymi. Wynik ten wskazuje na kluczowe znaczenie oznaczeń jakości, a w szczególności unijnego 
logo rolnictwa ekologicznego, które jest udzielane wraz z certyfikatem ekologicznym, na rynku żywności ekologicznej.

Ta interpretacja współgra z wynikami dotyczącymi kierowania się oznaczeniami jakości podczas zakupów ekologicznych produktów żywnościowych. Otóż istotna statystycznie różnica między osobami kierującymi się marką a pozostałymi wystąpiła także w tym pytaniu w odniesieniu do najszerszego agregatu marki: $\mathrm{EM} 1=3,28, \mathrm{P} 1=3,20, t=0,83, p=0,404 ; \mathrm{EM} 2=3,28, \mathrm{P} 2=3,19, t=1,11, p=0,268$; $\mathrm{EM} 3=3,32, \mathrm{P} 3=3,11, t=2,93, p=0,003$.

Mimo to nie stwierdzono istotnych różnic między osobami, dla których marka stanowi jedno z pięciu najważniejszych kryteriów wyboru żywności ekologicznej, a pozostałymi respondentami - niezależnie od sposobu definiowania marki - w zakresie: udziału (\%) żywności ekologicznej w zakupach produktów spożywczych $(\mathrm{EM} 1=25,59, \mathrm{P}=28,10, t=-1,21, p=0,227 ; \mathrm{EM} 2=28,45 ; \mathrm{P} 2=27,53$, $t=0,518, p=0,604$; EM3 $=28,27, \mathrm{P} 3=27,27, t=0,68, p=0,498)$ i skłonności do płacenia wyższej ceny za produkty ekologiczne w porównaniu z konwencjonalnymi (willingness to pay - WTP; EM1 = 16,08, P1 = 17,57, $t=-1,01, p=0,313$; EM2 = 17,27, P2 $=17,38, t=-0,08, p=0,933$; EM3 $=17,83$, P3 $=16,96, t=0,84, p=0,400)$. We wszystkich grupach badanych występował ponadto podobny poziom znajomości unijnego logo rolnictwa ekologicznego (kodowany w skali 1-3: „nie znam”, „słabo znam”, „dobrze znam”; EM1 = 2,17, P1 = 2,19, $t=-0,24, p=0,810$; EM2 = 2,18, $\mathrm{P} 2=2,18, t=-0,01, p=0,994 ; \mathrm{EM} 3=2,13, \mathrm{P} 3=2,22, t=-1,85, p=0,065)$.

Ankietowanych poproszono o ustosunkowanie się do 23 opinii na temat oznaczeń jakości stosowanych w odniesieniu do regionalnych i ekologicznych produktów żywnościowych (tab. 2.9). Gdy marka była definiowana wąsko - tylko w relacji do producenta - nie stwierdzono statystycznie istotnych różnic w zakresie tych opinii między osobami kierującymi się marką (EM1) a pozostałymi (P1). Gdy określenie marki obejmowało zarówno producenta, jak i sprzedawcę (EM2 v. P2), istotność statystyczną zauważono dla stwierdzenia, że europejskie oznaczenia jakości przyczyniają się do współpracy między producentami (integracja pozioma kanału rynku; $\boldsymbol{p}=\mathbf{0 , 0 4 2}$ ). Znacznie bardziej wyraziste podziały występują, gdy marka obejmuje również oznaczenia jakości (EM3 v. P3). Wówczas różnice są istotne statystycznie na poziomie $\boldsymbol{p}<\mathbf{0 , 0 5}$ aż dla 20 opinii. Osoby kierujące się tak rozumianą marką są pozytywniej nastawione do efektów europejskich oznaczeń jakości na rynku żywności. Potwierdzono tę zależność także przy zastosowaniu miernika syntetycznego, który został przez autora tego rozdziału nazwany percepcją europejskich oznaczeń jakości. Obejmuje on wszystkie stwierdzenia zawarte w tabeli 2.9, które są nacechowane pozytywnie. W sumie są to 22 opinie (z wyjątkiem „prowadzą do wyższych cen”, gdyż ta opinia może być oceniana pozytywnie lub negatywnie w zależności od punktu widzenia: producent v. kon- 
sument). Wskaźnik ten został zoperacjonalizowany jako średnia ocen w skali 1-5, w której 1 oznacza „zdecydowanie nie”, a 5 - „zdecydowanie tak”. W rezultacie zaobserwowano istotną statystycznie różnicę w zakresie tego wskaźnika przy najszerzej definiowanej marce (EM1 $=3,70, \mathrm{P} 1=3,64, t=0,95, p=0,340$; EM2 = 3,70, $\mathrm{P} 2=3,64, t=1,19, p=0,235$; EM3 $=3,75, \mathrm{P} 3=3,58, t=4,06, p<0,001)$, tzn. respondenci kierujący się marką obejmującą oznaczenia jakości mają lepszą średnią ocen tych oznaczeń stosowanych przez Komisję Europejską niż respondenci, dla których marka nie znalazła się wśród pięciu najważniejszych kryteriów wyboru żywności ekologicznej.

Tabela 2.9. Opinie na temat europejskich oznaczeń jakości dotyczących produktów regionalnych i ekologicznych

\begin{tabular}{|l|c|c|c|c|}
\hline \multicolumn{1}{|c|}{ Opinia } & EM1 & P1 & $t$ & $p$ \\
\hline Gwarantują stałą jakość produktu & 3,78 & 3,76 & 0,33 & 0,741 \\
\hline Prowadzą do wyższych cen & 3,89 & 3,87 & 0,27 & 0,786 \\
\hline Chronią autentyczność produktu & 3,90 & 3,81 & 1,10 & 0,272 \\
\hline $\begin{array}{l}\text { Całkowicie gwarantują, że produkt } \\
\text { pochodzi z danego obszaru }\end{array}$ & 3,81 & 3,74 & 0,90 & 0,367 \\
\hline Gwarantują ręczny wyrób produktów & 3,57 & 3,43 & 1,66 & 0,098 \\
\hline $\begin{array}{l}\text { Przyczyniają się do wzrostu zatrudnienia } \\
\text { w regionie pochodzenia }\end{array}$ & 3,61 & 3,54 & 0,82 & 0,412 \\
\hline Zmniejszają ryzyko imitacji produktów & 3,80 & 3,71 & 1,11 & 0,267 \\
\hline $\begin{array}{l}\text { Przyczyniają się do zachowania wyższej } \\
\text { jakości produktu }\end{array}$ & 3,74 & 3,77 & $-0,36$ & 0,719 \\
\hline $\begin{array}{l}\text { Przyczyniają się do wzrostu dochodów } \\
\text { rolniczych }\end{array}$ & 3,61 & 3,58 & 0,36 & 0,719 \\
\hline $\begin{array}{l}\text { Przyczyniają się do zachowania } \\
\text { ekskluzywności produktu }\end{array}$ & 3,77 & 3,68 & 1,13 & 0,259 \\
\hline $\begin{array}{l}\text { Gwarantują, że produkt jest wytwarzany } \\
\text { w tradycyjny sposób }\end{array}$ & 3,82 & 3,78 & 0,46 & 0,645 \\
\hline $\begin{array}{l}\text { Odróżniają produkt od żywności } \\
\text { konwencjonalnej }\end{array}$ & 3,87 & 3,86 & 0,11 & 0,914 \\
\hline Chronią producentów przed konkurencją & 3,64 & 3,54 & 1,19 & 0,235 \\
\hline Ułatwiają reklamę & 3,70 & 3,58 & 0,63 & 0,528 \\
\hline $\begin{array}{l}\text { Przyczyniają się do wzrostu lojalności } \\
\text { nabywców }\end{array}$ & 3,56 & 0,118 \\
\hline
\end{tabular}




\begin{tabular}{|c|c|c|c|c|}
\hline Opinia & EM1 & P1 & $t$ & $p$ \\
\hline $\begin{array}{l}\text { Zwiększają swobodę producentów } \\
\text { w ustalaniu cen }\end{array}$ & 3,56 & 3,49 & 1,01 & 0,314 \\
\hline $\begin{array}{l}\text { Przyczyniają się do współpracy między } \\
\text { producentami }\end{array}$ & 3,47 & 3,44 & 0,37 & 0,714 \\
\hline $\begin{array}{l}\text { Przyczyniają się do współpracy między } \\
\text { producentem a sprzedawcą }\end{array}$ & 3,56 & 3,52 & 0,45 & 0,651 \\
\hline $\begin{array}{l}\text { Ułatwiają nabywcom identyfikację } \\
\text { produktów oraz korzyści związanych z ich } \\
\text { konsumpcją }\end{array}$ & 3,85 & 3,75 & 1,25 & 0,212 \\
\hline $\begin{array}{l}\text { Skracają proces poszukiwania informacji } \\
\text { o produkcie }\end{array}$ & 3,62 & 3,61 & 0,11 & 0,912 \\
\hline Zmniejszają ryzyko towarzyszące zakupowi & 3,63 & 3,58 & 0,64 & 0,525 \\
\hline Podwyższają prestiż nabywcy w otoczeniu & 3,72 & 3,63 & 1,11 & 0,266 \\
\hline \multirow[t]{2}{*}{ Umożliwiają dbałość o zdrowie } & 3,70 & 3,73 & $-0,34$ & 0,733 \\
\hline & EM2 & P2 & $t$ & $p$ \\
\hline Gwarantują stałą jakość produktu & 3,76 & 3,76 & $-0,02$ & 0,985 \\
\hline Prowadzą do wyższych cen & 3,89 & 3,87 & 0,19 & 0,849 \\
\hline Chronią autentyczność produktu & 3,87 & 3,82 & 0,78 & 0,435 \\
\hline $\begin{array}{l}\text { Całkowicie gwarantują, że produkt } \\
\text { pochodzi z danego obszaru }\end{array}$ & 3,80 & 3,73 & 0,97 & 0,330 \\
\hline Gwarantują ręczny wyrób produktów & 3,53 & 3,43 & 1,33 & 0,183 \\
\hline $\begin{array}{l}\text { Przyczyniają się do wzrostu zatrudnienia } \\
\text { w regionie pochodzenia }\end{array}$ & 3,61 & 3,53 & 1,10 & 0,272 \\
\hline Zmniejszają ryzyko imitacji produktów & 3,74 & 3,72 & 0,30 & 0,762 \\
\hline $\begin{array}{l}\text { Przyczyniają się do zachowania wyższej } \\
\text { jakości produktu }\end{array}$ & 3,79 & 3,76 & 0,49 & 0,621 \\
\hline $\begin{array}{l}\text { Przyczyniają się do wzrostu dochodów } \\
\text { rolniczych }\end{array}$ & 3,58 & 3,59 & $-0,05$ & 0,963 \\
\hline $\begin{array}{l}\text { Przyczyniają się do zachowania } \\
\text { ekskluzywności produktu }\end{array}$ & 3,78 & 3,67 & 1,50 & 0,133 \\
\hline $\begin{array}{l}\text { Gwarantują, że produkt jest wytwarzany } \\
\text { w tradycyjny sposób }\end{array}$ & 3,80 & 3,78 & 0,25 & 0,800 \\
\hline $\begin{array}{l}\text { Odróżniają produkt od żywności } \\
\text { konwencjonalnej }\end{array}$ & 3,89 & 3,86 & 0,56 & 0,575 \\
\hline
\end{tabular}


Tabela 2.9. cd.

\begin{tabular}{|c|c|c|c|c|}
\hline & EM2 & P2 & $t$ & $p$ \\
\hline Chronią producentów przed konkurencją & 3,62 & 3,53 & 1,20 & 0,231 \\
\hline Ułatwiają reklamę & 3,74 & 3,63 & 1,72 & 0,086 \\
\hline $\begin{array}{l}\text { Przyczyniają się do wzrostu lojalności } \\
\text { nabywców }\end{array}$ & 3,64 & 3,58 & 0,99 & 0,321 \\
\hline $\begin{array}{l}\text { Zwiększają swobodę producentów } \\
\text { w ustalaniu cen }\end{array}$ & 3,58 & 3,48 & 1,55 & 0,122 \\
\hline $\begin{array}{l}\text { Przyczyniają się do współpracy między } \\
\text { producentami }\end{array}$ & 3,55 & 3,42 & 2,03 & 0,042 \\
\hline $\begin{array}{l}\text { Przyczyniają się do współpracy między } \\
\text { producentem a sprzedawcą }\end{array}$ & 3,57 & 3,51 & 0,96 & 0,338 \\
\hline $\begin{array}{l}\text { Ułatwiają nabywcom identyfikację } \\
\text { produktów oraz korzyści związanych z ich } \\
\text { konsumpcją }\end{array}$ & 3,82 & 3,74 & 1,10 & 0,274 \\
\hline $\begin{array}{l}\text { Skracają proces poszukiwania informacji } \\
\text { o produkcie }\end{array}$ & 3,61 & 3,61 & $-0,09$ & 0,930 \\
\hline Zmniejszają ryzyko towarzyszące zakupowi & 3,66 & 3,57 & 1,36 & 0,173 \\
\hline Podwyższają prestiż nabywcy w otoczeniu & 3,72 & 3,62 & 1,42 & 0,155 \\
\hline \multirow[t]{2}{*}{ Umożliwiają dbałość o zdrowie } & 3,73 & 3,73 & 0,05 & 0,961 \\
\hline & EM3 & P3 & $t$ & $p$ \\
\hline Gwarantują stałą jakość produktu & 3,87 & 3,67 & 3,55 & $<0,001$ \\
\hline Prowadzą do wyższych cen & 3,93 & 3,83 & 1,91 & 0,057 \\
\hline Chronią autentyczność produktu & 3,97 & 3,71 & 4,66 & $<0,001$ \\
\hline $\begin{array}{l}\text { Całkowicie gwarantują, że produkt } \\
\text { pochodzi z danego obszaru }\end{array}$ & 3,89 & 3,63 & 4,54 & $<0,001$ \\
\hline Gwarantują ręczny wyrób produktów & 3,53 & 3,39 & 2,47 & 0,014 \\
\hline $\begin{array}{l}\text { Przyczyniają się do wzrostu zatrudnienia } \\
\text { w regionie pochodzenia }\end{array}$ & 3,62 & 3,49 & 2,21 & 0,028 \\
\hline Zmniejszają ryzyko imitacji produktów & 3,83 & 3,63 & 3,47 & $<0,001$ \\
\hline $\begin{array}{l}\text { Przyczyniają się do zachowania wyższej } \\
\text { jakości produktu }\end{array}$ & 3,88 & 3,67 & 3,91 & $<0,001$ \\
\hline $\begin{array}{l}\text { Przyczyniają się do wzrostu dochodów } \\
\text { rolniczych }\end{array}$ & 3,63 & 3,55 & 1,43 & 0,152 \\
\hline $\begin{array}{l}\text { Przyczyniają się do zachowania } \\
\text { ekskluzywności produktu }\end{array}$ & 3,78 & 3,63 & 2,74 & 0,006 \\
\hline
\end{tabular}




\begin{tabular}{|l|c|c|c|c|}
\hline & EM3 & P3 & $t$ & $p$ \\
\hline $\begin{array}{l}\text { Gwarantują, że produkt jest wytwarzany } \\
\text { w tradycyjny sposób }\end{array}$ & 3,89 & 3,70 & 3,61 & $<\mathbf{0 , 0 0 1}$ \\
\hline $\begin{array}{l}\text { Odróżniają produkt od żywności } \\
\text { konwencjonalnej }\end{array}$ & 3,96 & 3,78 & $\mathbf{3 , 2 9}$ & $\mathbf{0 , 0 0 1}$ \\
\hline Chronią producentów przed konkurencją & 3,64 & 3,48 & $\mathbf{2 , 5 5}$ & $\mathbf{0 , 0 1 1}$ \\
\hline Ułatwiają reklamę & 3,74 & 3,59 & $\mathbf{2 , 7 1}$ & $\mathbf{0 , 0 0 7}$ \\
\hline $\begin{array}{l}\text { Przyczyniają się do wzrostu lojalności } \\
\text { nabywców }\end{array}$ & 3,70 & 3,51 & 3,50 & $<\mathbf{0 , 0 0 1}$ \\
\hline $\begin{array}{l}\text { Zwiększają swobodę producentów } \\
\text { w ustalaniu cen }\end{array}$ & 3,56 & 3,44 & $\mathbf{2 , 2 0}$ & $\mathbf{0 , 0 2 8}$ \\
\hline $\begin{array}{l}\text { Przyczyniają się do współpracy między } \\
\text { producentami }\end{array}$ & 3,54 & 3,37 & $\mathbf{3 , 0 0}$ & $\mathbf{0 , 0 0 3}$ \\
\hline $\begin{array}{l}\text { Przyczyniają się do współpracy między } \\
\text { producentem a sprzedawcą }\end{array}$ & 3,58 & 3,48 & 1,86 & 0,063 \\
\hline $\begin{array}{l}\text { Ułatwiają nabywcom identyfikację } \\
\text { produktów oraz korzyści związanych z ich } \\
\text { konsumpcją }\end{array}$ & 3,87 & 3,67 & $\mathbf{3 , 6 1}$ & $<\mathbf{0 , 0 0 1}$ \\
\hline $\begin{array}{l}\text { Skracają proces poszukiwania informacji } \\
\text { o produkcie }\end{array}$ & 3,67 & 3,56 & $\mathbf{2 , 0 1}$ & $\mathbf{0 , 0 4 5}$ \\
\hline Zmniejszają ryzyko towarzyszące zakupowi & 3,69 & 3,50 & $\mathbf{3 , 4 1}$ & $<\mathbf{0 , 0 0 1}$ \\
\hline Podwyższają prestiż nabywcy w otoczeniu & 3,71 & 3,58 & $\mathbf{2 , 3 7}$ & $\mathbf{0 , 0 1 8}$ \\
\hline Umożliwiają dbałość o zdrowie & 3,83 & 3,64 & $\mathbf{3 , 3 5}$ & $<\mathbf{0 , 0 0 1}$ \\
\hline
\end{tabular}

Źródto: badanie własne.

W opinii respondentów do najważniejszych kryteriów oceny autentyczności ekologicznych produktów żywnościowych należą naturalny smak i jakość produktu. W tabeli 2.10 przedstawiono porównanie relatywnego znaczenia poszczególnych kryteriów oceny autentyczności tego rodzaju produktów w zależności od kierowania się marką w trzech analizowanych ujęciach. Dla wszystkich trzech agregatów marki relatywnie większe znaczenie niż w całej próbie miały: europejskie oznaczenie jakości, nazwa produktu, miejsce sprzedaży na obszarze pochodzenia i wydzielone miejsce do ekspozycji w sklepach (wyrazisty merchandising). Natomiast relatywnie mniejsze znaczenie podczas oceny autentyczności wśród osób kierujących się marką w porównaniu z całą próbą miały: niska dostępność takich produktów, wygląd produktu i naturalny smak. 
Tabela 2.10. Kryteria oceny autentyczności ekologicznych produktów żywnościowych

\begin{tabular}{|l|r|r|r|r|}
\hline \multicolumn{1}{|c|}{ Kryterium } & EM1 & EM2 & EM3 & CP \\
\hline wiedza konsumenta & 23,2 & 23,7 & 21,9 & 22,0 \\
\hline niska dostępność takich produktów & 9,2 & 8,7 & 8,2 & 10,3 \\
\hline nazwa produktu & 16,9 & 15,1 & 13,4 & 12,7 \\
\hline etykieta & 31,0 & 26,9 & 31,0 & 29,0 \\
\hline wygląd produktu & 20,4 & 21,9 & 21,2 & 22,1 \\
\hline opakowanie & 16,2 & 18,3 & 17,3 & 18,2 \\
\hline miejsce sprzedaży - rodzaj sklepu & 26,8 & 28,8 & 23,8 & 24,8 \\
\hline $\begin{array}{l}\text { miejsce sprzedaży - na obszarze } \\
\text { pochodzenia }\end{array}$ & 14,8 & 12,3 & 11,7 & 10,7 \\
\hline adresowanie oferty do turystów & 5,6 & 6,8 & 6,1 & 5,9 \\
\hline europejskie oznaczenie jakości & 31,0 & 28,8 & 31,0 & 25,7 \\
\hline jakość produktu & 39,4 & 40,2 & 40,9 & 39,6 \\
\hline naturalny smak & 37,3 & 36,5 & 36,6 & 40,7 \\
\hline wydzielone miejsce do ekspozycji w sklepach & 26,8 & 27,4 & 26,4 & 24,6 \\
\hline inne & 0 & 0 & 0,2 & 1,2 \\
\hline
\end{tabular}

Uwaga: Respondenci zostali poproszeni o wskazanie trzech najważniejszych czynników, na podstawie których można ocenić autentyczność produktów ekologicznych.

Źródto: badanie własne.

Bezsprzecznie najważniejszą barierę rozwoju rynku żywności ekologicznej według ankietowanych stanowiła wysoka cena takich produktów. W tabeli 2.11 przedstawiono porównanie znaczenia poszczególnych barier w zależności od kierowania się marką. Relatywnie ważniejsze niż w całej próbie były następujące bariery: sceptycyzm wobec systemów certyfikacji i znakowania, niedostatecznie intensywne działania marketingowe i błędy w strategiach marketingowych. Natomiast mniejsze znaczenie niż w całej próbie odnotowano $\mathrm{w}$ odniesieniu do: wysokiej ceny produktów i zadowolenia z konsumpcji żywności konwencjonalnej (efekt substytucyjny).

Do najpopularniejszych kanałów dystrybucji żywności ekologicznej zdaniem ankietowanych należały sklepy z żywnością ekologiczną oraz targowiska, rynki i bazary. Znaczenie poszczególnych kanałów dystrybucji w zależności od kierowania się marką przedstawiono w tabeli 2.12. Osoby kierujące się marką częściej kupują żywność ekologiczną w sklepach należących do producenta, na kiermaszach 
Tabela 2.11. Bariery rozwoju rynku żywności ekologicznej

\begin{tabular}{|l|c|c|c|c|}
\hline \multicolumn{1}{|c|}{ Bariera } & EM1 & EM2 & EM3 & CP \\
\hline wysoka cena produktów & 61,3 & 56,6 & 61,7 & 63,1 \\
\hline niekorzystny wygląd produktów & 16,9 & 15,1 & 11,9 & 12,6 \\
\hline mała dostępność produktów & 32,4 & 33,3 & 32,0 & 33,2 \\
\hline $\begin{array}{l}\text { zadowolenie z konsumpcji zwykłych } \\
\text { produktów }\end{array}$ & 19,0 & 19,2 & 19,5 & 20,0 \\
\hline mała widoczność takich produktów w sklepie & 22,5 & 27,9 & 30,7 & 26,5 \\
\hline $\begin{array}{l}\text { sceptycyzm wobec systemów certyfikacji } \\
\text { i znakowania }\end{array}$ & 24,6 & 21,9 & 21,6 & 21,0 \\
\hline $\begin{array}{l}\text { niedostatecznie intensywne działania } \\
\text { marketingowe }\end{array}$ & 26,8 & 26,0 & 21,0 & 20,0 \\
\hline błędy w strategiach marketingowych & 16,2 & 20,5 & 17,3 & 15,8 \\
\hline $\begin{array}{l}\text { gorszy smak w porównaniu ze zwykłymi } \\
\text { produktami }\end{array}$ & 7,7 & 10,5 & 8,4 & 9,4 \\
\hline krótki termin przydatności do spożycia & 33,1 & 30,1 & 28,8 & 29,8 \\
\hline niedostateczna wiedza konsumentów & 37,3 & 34,7 & 36,6 & 35,3 \\
\hline inne & 0 & 0 & 0 & 0,8 \\
\hline
\end{tabular}

Uwaga: Respondenci zostali poproszeni o wskazanie trzech najważniejszych barier rozwoju rynku żywności ekologicznej.

Źródto: badanie własne.

z udziałem producentów, na festynach i imprezach zorganizowanych, w niezależnych sklepach detalicznych, w dużych sieciach handlowych, w punktach gastronomicznych i w Internecie. Natomiast respondenci, dla których marka stanowi kluczowe kryterium wyboru, rzadziej niż cała próba zaopatrują się w żywność ekologiczną na targowiskach, rynkach i bazarach. Różnice te mogą (po części) wynikać z odmiennego sposobu rozumienia pojęcia „żywność ekologiczna” - czy są to wyłącznie produkty certyfikowane, czy także pochodzące z gospodarstw rolnych stosujących ekologiczne metody produkcji, ale nieposiadających certyfikatu.

Następnie podjęto próbę analizy zjawiska etnocentryzmu konsumenckiego na rynku żywności ekologicznej w zależności od kierowania się marką. Nie odnotowano istotnych statystycznie różnic w zakresie udziału produktów pochodzących $\mathrm{z}$ regionu konsumenta $\mathrm{w}$ zakupach żywności ekologicznej (\%) między osobami kierującymi się marką a pozostałymi respondentami $(\mathrm{EM} 1=22,75, \mathrm{P} 1=25,68$, $t=-1,26, p=0,209$; EM2 $=25,72, \mathrm{P} 2=25,12, t=0,30, p=0,763$; $\mathrm{EM} 3=24,00$, 
Tabela 2.12. Kanały dystrybucji żywności ekologicznej

\begin{tabular}{|l|r|r|c|c|}
\hline \multicolumn{1}{|c|}{ Kanał dystrybucji } & EM1 & EM2 & EM3 & CP \\
\hline $\begin{array}{l}\text { bezpośrednio gospodarstwo rolne } \\
\text { producenta }\end{array}$ & 22,5 & 19,2 & 19,9 & 20,5 \\
\hline sklepy należące do producenta & 21,1 & 21,0 & 19,0 & 16,5 \\
\hline targowiska, rynki, bazary & 24,6 & 27,9 & 29,4 & 30,1 \\
\hline kiermasze z udziałem producentów & 23,9 & 22,8 & 24,3 & 20,5 \\
\hline festyny, imprezy zorganizowane & 16,2 & 14,2 & 14,4 & 14,1 \\
\hline sklepy z żywnością ekologiczną & 40,1 & 37,0 & 42,5 & 38,8 \\
\hline niezależne sklepy detaliczne & 16,2 & 16,4 & 15,7 & 12,7 \\
\hline $\begin{array}{l}\text { duże sieci handlowe (hipermarkety, } \\
\text { supermarkety, dyskontowe itp.) }\end{array}$ & 29,6 & 30,1 & 27,2 & 27,0 \\
\hline punkty gastronomiczne & 6,3 & 7,8 & 6,0 & 5,4 \\
\hline Internet & 9,2 & 9,6 & 8,2 & 6,3 \\
\hline inne & 0 & 0 & 0 & 0,1 \\
\hline
\end{tabular}

Uwaga: Respondenci zostali poproszeni o wskazanie wszystkich kanałów dystrybucji, w których zaopatrują się w żywność ekologiczną.

Źródło: badanie własne.

P3 $=26,35, t=-1,43, p=0,154)$, zatem przynajmniej w sferze deklaracji kierowanie się marką nie wpływa na preferowanie żywności ekologicznej z regionu konsumenta. Potwierdzono to również, gdy konsumenci zostali poproszeni o określenie znaczenia pochodzenia produktu z ich regionu podczas zakupów żywności ekologicznej ( $\mathrm{EM} 1=3,36, \mathrm{P} 1=3,36, t=0,01, p=0,990$; $\mathrm{EM} 2=3,42, \mathrm{P} 2=3,34, t=0,83$, $p=0,409 ; \mathrm{EM} 3=3,39, \mathrm{P} 3=3,33, t=0,88, p=0,378)$. Klasyczny etnocentryzm na poziomie kraju był zróżnicowany, gdy marka została zdefiniowana najszerzej, tj. z uwzględnieniem oznaczeń jakości. Wówczas osoby kierujące się marką charakteryzowały się istotnie wyższym poziomem etnocentryzmu od pozostałych badanych $(\mathrm{EM} 1=3,92, \mathrm{P} 1=3,88, t=0,39, p=0,696$; EM2 $=3,93, \mathrm{P} 2=3,88, t=0,64$, $p=0,519 ; \mathrm{EM} 3=4,01, \mathrm{P} 3=3,79, t=3,19, p=0,001)$. Kierowanie się marką nie miało natomiast wpływu na częstość zakupu ekologicznych produktów żywnościowych przez turystów $(\mathrm{EM} 1=2,93, \mathrm{P} 1=2,99, t=-0,56, p=0,576$; EM2 $=3,06, \mathrm{P} 2=2,96$, $t=1,14, p=0,256$; $\mathrm{EM} 3=3,02, \mathrm{P} 3=2,95, t=0,96, p=0,339$ ).

W celu określenia determinant kierowania się marką na rynku ekologicznych produktów żywnościowych posłużono się modelami regresji logistycznej. 
W związku z ujawnieniem większej liczby różnic istotnych statystycznie podczas analiz powyższych zależności jako zmienną zależną przyjęto kierowanie się marką w najszerszym ujęciu, tj. obejmującym markę producenta, miejsca sprzedaży i oznaczenia jakości. Najpierw przeprowadzono szereg analiz z wybranymi zmiennymi niezależnymi. W modelach z jedną zmienną niezależną ustalono, że kierowanie się marką na rynku żywności ekologicznej zależy od:

1) znaczenia oznaczeń jakości w procesie zakupu (jakichkolwiek) produktów żywnościowych $(\mathrm{OR}=1,29, p<0,001)$;

2) znaczenia marki w procesie zakupu (jakichkolwiek) produktów żywnościowych $(\mathrm{OR}=1,23, p=0,003)$;

3) stosunku do żywności ekologicznej (OR = 1,23, $p=0,003)$;

4) kierowania się oznaczeniami jakości podczas zakupów ekologicznych produktów żywnościowych $(\mathrm{OR}=1,18, p=0,004)$;

5) percepcji europejskich oznaczeń jakości (OR = 1,49, $p<0,001)$;

6) uznawania europejskiego oznaczenia jakości jako kluczowego kryterium oceny autentyczności ekologicznych produktów żywnościowych $(\mathbf{O R}=\mathbf{1 , 7 6}$, $p<0,001)$

7) wskazywania słabego merchandisingu jako kluczowej bariery rozwoju rynku ekologicznych produktów żywnościowych $(\mathrm{OR}=1,58, p=0,001)$;

8) znaczenia pochodzenia produktu z Polski podczas zakupów żywności ekologicznej $(\mathrm{OR}=1,21, p=0,002)$;

9) wieku respondenta $(\mathrm{OR}=\mathbf{1 , 0 1}, p=\mathbf{0 , 0 0 7})$;

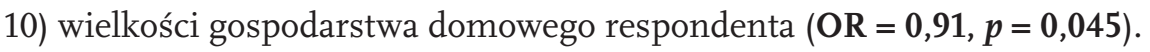

Wartości ilorazu szans (odds ratio - OR) powyżej jedności oznaczają, że dana cecha zwiększa prawdopodobieństwo wystąpienia zmiennej zależnej, czyli np. większe znaczenie oznaczeń jakości jako atrybutu produktów żywnościowych zwiększa prawdopodobieństwo kierowania się marką jako kryterium wyboru żywności ekologicznej. Należy zauważyć, że dla podanych wyżej cech OR > 1 - z wyjątkiem wielkości gospodarstwa domowego - zatem im większa rodzina respondenta, tym mniejsze prawdopodobieństwo kierowania się marką podczas zakupu żywności ekologicznej. Warto dodać, że przedmiotem analizy w modelach regresji logistycznej z jedną zmienną niezależną była jeszcze jedna cecha: naturalny smak jako kluczowe kryterium oceny autentyczności ekologicznych produktów żywnościowych. Jednakże nie uzyskano istotności statystycznej podczas analizy wpływu tego czynnika (OR $=0,78, p=0,053$ ). Przy tym kierunek ewentualnej zależności w tym przypadku także byłby odwrotny, tzn. wskazywanie naturalnego smaku jako kluczowego kryterium oceny autentyczności żywności ekologicznej zmniejsza prawdopodobieństwo kierowania się marką na tym rynku (aczkolwiek w sposób nieistotny statystycznie, na poziomie $p<0,05)$. 
Tabela 13. Uwarunkowania kierowania się marką na rynku żywności ekologicznej (model regresji logistycznej)

\begin{tabular}{|l|c|c|c|c|c|}
\hline \multicolumn{1}{|c|}{ Zmienne niezależne } & OR & $\mathbf{- 9 5 \% ~ C L ~}$ & +95\% CL & $t$ & $p$ \\
\hline znaczenie oznaczeń jakości (1) & 1,17 & 1,00 & 1,36 & 2,00 & $\mathbf{0 , 0 4 6}$ \\
\hline percepcja oznaczeń jakości (2) & 1,33 & 1,07 & 1,64 & 2,63 & $\mathbf{0 , 0 0 9}$ \\
\hline $\begin{array}{l}\text { ocena autentyczności - } \\
\text { oznaczenie (3) }\end{array}$ & 1,63 & 1,21 & 2,19 & 3,24 & $\mathbf{0 , 0 0 1}$ \\
\hline ocena autentyczności - smak (4) & 0,75 & 0,58 & 0,98 & $-2, \mathbf{1 1}$ & $\mathbf{0 , 0 3 6}$ \\
\hline bariera - merchandising (5) & 1,54 & 1,15 & 2,06 & 2,94 & $\mathbf{0 , 0 0 3}$ \\
\hline wiek respondenta (6) & 1,01 & 1,00 & 1,02 & 2,66 & $\mathbf{0 , 0 0 8}$ \\
\hline
\end{tabular}

Uwaga: (1) jako atrybutu produktów żywnościowych; (2) europejskich; (3) wskazywanie europejskiego oznaczenia jakości jako kluczowego kryterium oceny autentyczności ekologicznych produktów żywnościowych; (4) wskazywanie naturalnego smaku jako kluczowego kryterium oceny autentyczności ekologicznych produktów żywnościowych; (5) wskazywanie słabego merchandisingu jako kluczowej bariery rozwoju rynku ekologicznych produktów żywnościowych; (6) w latach.

Źródło: badanie własne.

Oprócz niezależnego wpływu poszczególnych zmiennych na kierowanie się marką w badaniu próbowano ustalić jednoczesny wpływ kilku zmiennych. W tym celu skonstruowano serię modeli regresji logistycznej z wieloma zmiennymi niezależnymi. Sukcesywnie eliminowano z nich te zmienne, które traciły istotność statystyczną w połączeniu z pozostałymi zmiennymi. W rezultacie otrzymano model z sześcioma zmiennymi niezależnymi (tab. 2.13). Cały model jest silnie istotny statystycznie: $\chi^{2}(\mathbf{6})=\mathbf{5 2 , 9}, p<\mathbf{0 , 0 0 0 1}$, co dobrze świadczy o jego dopasowaniu do analizowanego zjawiska. Ponadto każda zmienna niezależna zawarta $\mathrm{w}$ tym modelu jest istotna statystycznie na poziomie $p<0,05$. Ustalono, że kierowanie się marką (w szerokim ujęciu) podczas wyboru ekologicznych produktów żywnościowych zależy od:

1) znaczenia oznaczeń jakości jako atrybutu produktów żywnościowych (w skali 1-5);

2) percepcji europejskich oznaczeń jakości (w skali 1-5);

3) wskazywania europejskiego oznaczenia jakości jako kluczowego kryterium oceny autentyczności ekologicznych produktów żywnościowych (jednego z trzech najważniejszych);

4) wskazywania naturalnego smaku jako kluczowego kryterium oceny autentyczności ekologicznych produktów żywnościowych (jednego z trzech najważniejszych); 
5) wskazywania słabego merchandisingu jako kluczowej bariery rozwoju rynku ekologicznych produktów żywnościowych (jednego z trzech najważniejszych);

6) wieku respondenta (w latach).

Wszystkie powyższe zmienne wzmacniają kierowanie się marką na rynku żywności ekologicznej - z wyjątkiem oceny autentyczności przez pryzmat smaku, która daje przeciwny efekt.

\section{UWAGI KOŃCOWE}

W tym rozdziale podjęto problematykę znaczenia marki na rynku ekologicznych produktów żywnościowych. Analizy oparto na wynikach badania ankietowego w reprezentatywnej próbie 1000 mieszkańców Polski w wieku 15-65 lat. Perspektywa konsumenta wydaje się kluczowa z punktu widzenia tematu tego rozdziału. Niemniej w przyszłości może zostać uzupełniona badaniami wśród pozostałych uczestników rynku, w szczególności producentów i dystrybutorów. Znaczenie marki określono na podstawie odpowiedzi na pytanie: jakie są najważniejsze kryteria wyboru żywności ekologicznej? Wskazanie marki jako jednego z pięciu najważniejszych kryteriów było podstawą rozróżnienia osób kierujących się marką od pozostałych respondentów. Należy w tym miejscu jeszcze raz podkreślić, że marka może być definiowana w różny sposób. W tym rozdziale przeanalizowano trzy poziomy agregacji marki:

1) producenta;

2) producenta i sprzedawcy;

3) producenta, sprzedawcy i oznaczenia jakości.

Trzeci poziom definicyjny wydaje się najwłaściwszy, biorąc pod uwagę specyfikę rynku żywności ekologicznej, gdyż odgrywają na nim bardzo ważną rolę oznaczenia jakości i certyfikaty, które mają znamiona marek kolektywnych. W zależności od sposobu definiowania marki ustalono, że stanowi ona kluczowe kryterium wyboru dla odpowiednio 14,2\%, 21,9\% i 45,2\% badanych. Dla konsumentów kierujących się marką (na każdym z trzech poziomów agregacji) określono pozostałe kryteria wyboru żywności ekologicznej, porównując je z wynikami w całej próbie. Ponadto przeanalizowano strukturę tych grup badanych w porównaniu z osobami kierującymi się innymi kryteriami wyboru żywności ekologicznej. Oprócz podstawowych cech demograficzno-społecznych analizie poddano wybrane kryteria psychograficzne, w szczególności opinie dotyczące rynku żywności ekologicznej. W modelu regresji logistycznej podjęto próbę identyfikacji czynników mających wpływ na znaczenie przypisywane marce w procesie wyboru żywności ekologicznej. Gdy marka jest definiowana najszerzej (tj. obejmuje markę producenta, miejsca sprzedaży i oznaczenia jakości), stwierdzono istotny statystycznie wpływ 
sześciu zmiennych na znaczenie przypisywane marce na tym rynku. Prawdopodobieństwo kierowania się marką wzrasta wraz z:

1) rosnącym znaczeniem oznaczeń jakości;

2) pozytywną percepcją oznaczeń jakości;

3) oceną autentyczności produktów przez pryzmat oznaczeń jakości;

4) wskazywaniem słabego merchandisingu jako kluczowej bariery rozwoju rynku żywności ekologicznej;

5) wiekiem respondenta.

Prawdopodobieństwo kierowania się marką maleje, gdy autentyczność jest oceniana za pomocą smaku. Wyniki te potwierdzają bardzo silne powiązanie marki z systemem oznaczeń jakości stosowanych na rynku żywności ekologicznej.

\section{BIBLIOGRAFIA}

Anisimova T., Sultan P., The role of brand communications in consumer purchases of organic foods: A research framework, „Journal of Food Products Marketing”, 2014, 20(5), s. 511-532.

Bartels J., Hoogendam K., The role of social identity and attitudes toward sustainability brands in buying behaviors for organic products, „Journal of Brand Management”, 2011, 18(9), s. 697-708.

Bauer H., Heinrich D., Schäfer D., The effects of organic labels on global, local, and private brands. More hype than substance?, „Journal of Business Research”, 2013, 66(8), s. 1035-1043.

Bryła P., Organic food online shopping in Poland, „British Food Journal”, 2018, 120(5), s. 1015-1027.

Bryła P., Organic food consumption in Poland: motives and barriers, „Appetite”, 2016, 105, s. 737-746.

Bryła P., Marketing regionalnych i ekologicznych produktów żywnościowych - perspektywa sprzedawcy $i$ konsumenta, Wydawnictwo Uniwersytetu Łódzkiego, Łódź 2015.

Bryła P., The role of appeals to tradition in origin food marketing: a survey among Polish consumers, „Appetite”, 2015, 91, s. 302-310.

Bryła P., The impact of EU accession on the marketing strategies of Polish food companies, „British Food Journal", 2012, 114(8), s. 1196-1209.

Domański T., Bryła P., Marketing produktów żywnościowych, PWE, Warszawa 2010.

Drexler D., Fiala J., Havlíčková A., Potůčková A., Souček M., The effect of organic food labels on consumer attention, „Journal of Food Products Marketing”, 2018, 24(4), s. 441-455.

Ellison B., Duff B., Wang Z., White T., Putting organic label in context: Examining the interactions between the organic label, product type, and retail outlet, „Food Quality and Preference”, 2016, 49, s. 140-150.

Garbarski L., Rutkowski I., Wrzosek W., Marketing, PWE, Warszawa 2000.

Górska-Warsewicz H., Żakowska-Biemans S., Czeczotko M., Świątkowska M., Stangierska D., Świstak E., Bobola A., Szlachciuk J., Krajewski K., Organic private labels as sources of competitive advantage - the case of international retailers operating on the Polish market, „Sustainability”, 2018, 10(7), 2338, s. 1-28.

Grzybowska-Brzezińska M., Grzywińska-Rąpca M., Atrybuty żywności ekologicznej determinujące wybory konsumentów, „Zeszyty Naukowe Szkoły Głównej Gospodarstwa Wiejskiego. Ekonomika i Organizacja Gospodarki Żywnościowej”, 2016, nr 114, s. 57-68.

Larceneux F., Benoit-Moreau F., Renaudin V., Why might organic labels fail to influence consumer choices? Marginal labelling and brand equity effects, "Journal of Consumer Policy”, 2012, 35(1), s. 85-104. 
Llorens M., Carcelén S., The role of private labels in the organic food market, [w:] Handbook of research on strategic retailing of private label products recovering economy, red. M. Gómez-Suárez, M. Martínez-Ruiz, IGI Global, Hershey 2016, s. 359-387.

Pilarczyk B., Nestorowicz R., Marketing ekologicznych produktów żywnościowych, Wolters Kluwer, Warszawa 2010.

Reinders M., Bartels J., The roles of identity and brand equity in organic consumption behavior: Private label brands versus national brands, „Journal of Brand Management”, 2017, 24(1), s. 68-85.

Ryan J., Casidy R., The role of brand reputation in organic food consumption: A behavioral reasoning perspective, „Journal of Retailing and Consumer Services”, 2018, 41, s. 239-247.

Schäfer D., Heinrich D., Green branding: Do local and global brands benefit from organic labeling, [w:] The Sustainable Global Marketplace, red. M. Conway, Springer, Cham 2015, s. 443.

Stanton J., Guion D., Perceptions of "organic" food: A view through brand theory, "Journal of International Food and Agribusiness Marketing", 2015, 27(2), s. 120-141.

\section{STRESZCZENIE}

W tym rozdziale przedstawiono ocenę znaczenia marki na rynku ekologicznych produktów żywnościowych, jak również wskazano czynniki wpływające na to znaczenie. Analizy oparto na wynikach badania ankietowego przeprowadzonego metodą CAWI w reprezentatywnej próbie 1000 mieszkańców Polski w wieku 15-65 lat. W modelu regresji logistycznej ustalono, iż prawdopodobieństwo kierowania się marką wzrasta wraz z: rosnącym znaczeniem oznaczeń jakości, pozytywną percepcją oznaczeń jakości, oceną autentyczności produktów przez pryzmat oznaczeń jakości, wskazywaniem słabego merchandisingu jako kluczowej bariery rozwoju rynku żywności ekologicznej i wiekiem respondenta. Natomiast maleje, gdy autentyczność jest oceniana za pomocą smaku.

\section{Słowa kluczowe}

żywność ekologiczna, marka, oznaczenia jakości, autentyczność, zachowania konsumentów

\section{THE IMPORTANCE OF THE BRAND ON THE MARKET OF ORGANIC FOOD PRODUCTS}

\section{ABSTRACT}

This chapter aims at assessing the importance of the brand on the market of organic food products as well as indicating its predictors. The analyses are based on a survey carried out with the CAWI method in a representative sample of 1,000 inhabitants of Poland aged 15-65. In a logistic regression model, the probability of being driven by the brand increases with: 1) an increasing importance of quality signs, 2) a positive perception of quality signs, 3) evaluating product authenticity through quality signs, 4) indicating weak merchandising as a key barrier to the development of the organic food market, and 5) the respondent's age. It decreases when the authenticity is evaluated through taste.

\section{Keywords}

organic food, brand, quality signs, authenticity, consumer behaviour 


\section{BIOGRAM}

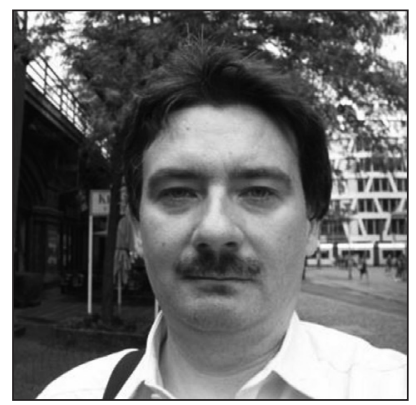

Dr hab. Paweł Bryła jest profesorem Uniwersytetu Łódzkiego w Katedrze Marketingu Międzynarodowego i Dystrybucji na Wydziale Studiów Międzynarodowych i Politologicznych. Jest absolwentem stosunków międzynarodowych na Uniwersytecie Łódzkim i studiów podyplomowych z zakresu integracji europejskiej w Kolegium Europejskim w Brugii. Doktorat i habilitację uzyskał na Wydziale Zarządzania Uniwersytetu Łódzkiego. Jego zainteresowania naukowe koncentrują się wokół marketingu regionalnych i ekologicznych produktów żywnościowych, roli informacji związanych ze zdrowiem na rynku żywności, zjawisk etnocentryzmu konsumenckiego i efektu kraju pochodzenia oraz międzynarodowej mobilności studentów. Jest autorem ponad 100 publikacji naukowych, w tym artykułów w czołowych czasopismach międzynarodowych (m.in. „Appetite”, „British Food Journal”, „Quality Assurance and Safety of Crops \& Foods”, „Academy of Management Learning and Education”). Jego prace były cytowane 231 razy w bazie Web of Science Core Collection i 821 razy w Google Scholar. Prof. Bryła obecnie kieruje dwoma projektami badawczymi finansowanymi z grantów Narodowego Centrum Nauki. Kierował polskim zespołem w międzynarodowym projekcie badawczym MERGE, finansowanym przez Komisję Europejską. Był laureatem dwóch edycji programu Iuventus Plus dla wybitnych młodych naukowców oraz stypendystą Ministra Nauki i Szkolnictwa Wyższego. Otrzymał Nagrodę Prezydium Oddziału Polskiej Akademii Nauk i Konferencji Rektorów Łódzkich Uczelni Publicznych, Nagrodę Marszałka Województwa Łódzkiego, Nagrodę im. Prof. Witolda Kuli i 11 nagród rektorskich. Przez 8 lat pełnił funkcję Wydziałowego Pełnomocnika Rektora ds. Programu Erasmus. Współpracuje z Narodowym Centrum Nauki, Narodowym Centrum Badań i Rozwoju i Narodową Agencją Wymiany Akademickiej jako ekspert. Jest członkiem rad redakcyjnych międzynarodowych czasopism naukowych, m.in. „European Journal of International Management” i „Journal of Management and Business Administration. Central Europe", jak również wydawnictwa Cambridge Scholars Publishing. 